\title{
AKTIVITAS ANTIBAKTERI EKSTRAK DAN FRAKSI KARANG LUNAK Sinularia SP. DI TELUK MANADO
}

\author{
Lyone Katiandagho' $^{1)}$, Defny Silvia Wewengkang ${ }^{1)}$, Sri Sudewi ${ }^{1)}$ \\ ${ }^{1)}$ Program Studi Farmasi Fakultas MIPA UNSRAT Manado, 95115
}

\begin{abstract}
Soft Coral Sinularia sp.has been shown to have antibacterial activity. This research aims to determine the antibacterial activity of marine organisms obtained from Manado bay. The method in this study is the diffusion method with positive control chloramphenicol and negative control of methanol in Escerichia coli and Sthaphylococcus aureus. The result showed that extracts, chloroform fraction and methanol-water fraction were obtained inhibiting category of Sthapylococcus aureus bacteria, but in the chloroform fraction and ethanol extract can inhibit Escerichia coli bacteria categorized as strong. With it can be conlueded that the extract and fraction of soft Sinularia sp. have bioactive compounds with a broth spectrum of antibacterial activity.
\end{abstract}

Keywords: Sinularia sp., Chloramphenicol, Escerichia coli, Sthaphylococcus aureus, and antibacterial.

\begin{abstract}
ABSTRAK
Karang lunak Sinularia sp. telah terbukti memiliki aktivitas antibakteri. Penelitian ini bertujuan untuk mengetahui aktivitas antibakteri pada organisme biota laut yang diperoleh dari teluk Manado. Metode dalam penelitian ini adalah metode difusi agar dengan kontrol positif kloramfenikol dan kontrol negatit metanol pada Escherichia coli dan Staphylococcus aureus. Hasil penelitian menunjukkan bahwa ekstrak, fraksi kloroform, dan fraksi metanol-air dapat menghambat bakteri Staphylococcus aereus dikategorikan sedang, namun pada fraksi kloroform dan ekstrak etanol dapat menghambat bakteri Escerichia coli dikategorikan kuat. Dengan demikian dapat disimpulkan bahwa ekstrak dan fraksi karang lunak Sinularia sp.memiliki senyawa bioaktif dengan spektrum yang luas terhadap aktivitas antibakteri.
\end{abstract}

Kata kunci: Sinularia sp, Kloramfenikol, Escherichia coli, Staphylococcus aureus, dan antibakteri 


\section{PENDAHULUAN}

Laut menutupi $71 \%$ dari permukaan bumi, oleh sebab itu sangat banyak potensi yang bisa diambil dari laut seperti sumber makanan, zat warna kosmetik, bahkan obat-obatan. Dewasa ini pemanfaatan organisme laut banyak digunakan sebagai sumber obat baru. Hal ini disebabkan oleh kemampuan organisme laut seperti tumbuhan dan invertebrata laut dalam memproduksi senyawa kimia yang mempunyai keanekaragaman hayati yang tinggi dengan struktur kimia yang khas. Banyak senyawa aktif yang diisolasi dari bahan alam bahari yang memberikan dengan aktivitas biologinya (Ellis and Sharon, 2005).

Berbagai penelitian menunjukkan bahwa organisme laut memiliki potensi yang sangat besar dalam menghasilkan senyawa-senyawa aktif yang dapat digunakan sebagai bahan baku obat-obatan. Beberapa organisme laut yang diketahui dapat menghasilkan senyawa aktif antara lain ialah spons, moluska, bryozoa, tunikata, karang lunak dan lain-lain. Organismeorganisme ini diketahui dapat menghasilkan sejumlah besar produk laut yang bersifat alami, juga mampu menunjukkan keragaman senyawa kimia yang sangat besar (Thakur and Muller, 2004).

Karang lunak berperan sebagai salah satu hewan penyusun ekosistem terumbu karang serta pemasok senyawa pertumbuhan terbesar bagi terumbu karang yaitu senyawa karbonat, hal ini dibuktikan dengan penemuan sejumlah besar spikula berkapur di dalam jaringan tubuhnya dan ini tidak ditemukan pada hewan-hewan lain yang hidup sekalipun diterumbu karang yang sama. Berdasarkan laporan pada dekade terakhir ini ditemukan bahwa tenyata sebanyak 50\% senyawa bioaktif yang terdapat pada invertebrata ini bersifat toksik. Karang lunak pada waktu diambil dari laut umumnya mempunyai bau atau aroma yang tajam (Radhika, 2006).
Sinularia sp. Merupakan salah satu jenis karang lunak yang belakangan ini banyak dikaji kandungan bioaktifnya. Mengingat potensi dari karang lunak terutama Sinularia sp. Yang mempunyai kandungan bioaktif yang besar, maka peneliti tertarik untuk meneliti karang lunak Sinularia sp. Yang terdapat di Teluk Manado untuk melihat aktivitas antibakterinya.

\section{METODE PENELITIAN}

Penelitian ini menggunakan metode Eksperimental Laboratorium yaitu dengan menguji aktivitas dari fraksi teripang laut (Sinularia sp.) terhadap bakteri Escherichia coli dan Staphylococcus aureus.

\section{Preparasi Sampel}

Pada penelitian ini sampel teripang laut dikoleksi dari perairan pantai Malalayang kota Manado, dengan menggunakan alat bantu (masker, fins, dan shorkel).

1. Pengambilan sampel di ambil di Teluk Manado

2. Ekstraksi bahan aktif sampelmenggunakan metode maserasi dengan pelarut etanol $96 \%$.

3. Fraksinasi sampel menggunakan larutan metanol, n-heksan, dan kloroform.

\section{Pembuatan Media dan Pengujian Antibakteri}

1. Sterilisasi alat

2. Kultur bakteri

3. Pembuatan larutan kontrol negatif dan positif

4. Pembuatan larutan uji

5. Pengujian aktivitas antibakteri, metode yang dalam penelitian ini yaitu metode difusi agar (disc diffusion Kirby and Bauer).

6. Pengamatan dapat dilakukan setelah 1x24 jam masa inkubasi dan diameter zona hambat diukur dalam satuan millimeter $(\mathrm{mm})$ menggunakan mistar berskala dengan cara diukur diameter total zona bening cakram. 
PHARMACON- PROGRAM STUDI FARMASI, FMIPA, UNIVERSITAS SAM RATULANGI,

Volume 8 Nomor 1 Februari 2019

HASIL DAN PEMBAHASAN

Ekstraksi Sampel
Pada penilitian ini ekstraksi karang lunak Sinularia sp. ialah maserasi.

Tabel 1. Hasil Ekstraksi dan Rendemen Ekstrak Sinularia sp.

\begin{tabular}{llll}
\hline Sampel Segar & Filtrat (Warna) & Ekstrak Kasar Rendemen & Ekstrak Kasar
\end{tabular}
$(\mathrm{g})$
$(\mathrm{g})$
$(\%)$
(Warna)

120,8 Cokelat Pekat $\quad 6,28 \quad 5,2 \quad$ Cokelatkehitaman

Keterangan : Ekstraksi menggunakan pelarut etanol $96 \%$

Berdasarkan tabel di atas, hasil ekstraksi menggunakan pelarut etanol $96 \%$ didapati filtrat berwarna cokelat pekat dengan berat $120,8 \mathrm{~g}$, filtrat tersebut kemudian disaring kembali untuk memisahkan garam dari ekstrak dengan tujuan, agar dalam pengujian antibakteri garam tidak mengganggu penghambatan bakteri.Filtrat selanjutnya diuapkan menggunakan rotary evaporator untuk memisahkan pelarut dan ekstrak sehingga didapati ekstrak kasar etanol

\section{Fraksinasi Sampel}

Pada penelitian ini, fraksinasi dilakukan dengan metode FCC (Fraksinasi Cair-Cair) berwarna cokelat kehitaman dengan berat $6,28 \mathrm{~g}$ dan rendemen berkisar 5,2\%. Hal ini disebabkan oleh karena ukuran sampel mempengaruhi suatu rendemen.

Ekstrak etanol yang diperoleh selanjutnya disimpan didalam lemari pendingin untuk menjaga agar tidak terjadi kerusakan kandungan bioaktifnya dan selanjutnya diuji aktivitas antibakteri utuk mengetahui bahwa ekstrak tersebut memiliki daya hambat terhadap bakteri uji.

dengan pelarut $\mathrm{n}$-heksan, kloroform dan metanol secara berkesinambungan dengan sifat kepolaran pelarut yang berbeda-beda.

Tabel 2. Hasil Fraksinasi dan Rendemen Fraksi

\begin{tabular}{llll}
\hline Sampel & Berat Fraksi $(\mathbf{g})$ & Rendemen $(\%)$ & Warna \\
FH & 0,22 & 22 & Hijau \\
FK & 0,37 & 37 & Coklat Kehitaman \\
FMA & 0,24 & 24 & Cokelat \\
\hline
\end{tabular}

Keterangan :

$\mathrm{FH}=$ Fraksi Heksan

FK = Fraksi Kloroform

FMA $=$ Fraksi Metanol-Air

Berdasarkan tabel diatas, partisi menggunakan pelarut n-heksan, didapati fraksi n-heksan berwana hijau dengan berat $0,22 \mathrm{~g}$ dan rendemen berkisar $22 \%$, untuk pelarut kloroform didapati fraksi berwarna cokelat kehitaman dengan berat $0,37 \mathrm{~g}$ dan rendemen berkisar $37 \%$ dan metanol didapati fraksi berwarna coklat dengan berat $0,24 \mathrm{~g}$, serta rendemen berkisar $24 \%$. Ketiga rendemen menunjukkan perbedaan yang nyata seperti rendemen yang dihasilkan oleh fraksi kloroform lebih besar dibanding dengan rendemen metanol-air dan n-heksan hal ini disebabkan oleh karena adanya 
perbedaan kelarutan komponen dalam sampel.

\section{Uji Aktivitas Antibakteri}

Uji aktivitas antibakteri ekstraketanol, fraksi $\mathrm{MeOH}$-air, fraksi n-heksan dan fraksi kloroform Karang Lunak Sinularia sp. dilakuan terhadap bakteri Escherichia coli dan Staphylococcus aureus dengan metode difusi agar. Metode difusi agar (difusi Kirby - Bauer yang telah dimodifikasi) menjadi pilihan untuk tujuan klinis yang mempertimbangkan kesederhanaan teknik, ketelitian, metode serbaguna bagi semua bakteri patogen yang tumbuh cepat dan sering digunakan dalam uji kepekaan antibiotik dalam program pengendalian mutu (Mpila, 2012).

Hasil uji aktivitas antibakteri dan hasil pengukuran diameter zona hambat ekstrak etanol,Fraksi $\mathrm{MeOH}$-air, fraksi heksan dan fraksi kloroform Karang lunakSinularia sp. terhadap bakteri Staphylococcus aureus dan Escherichia coli dapat dilihat padagambar 5 dan Tabel 3 dan 4.

Tabel 3. Hasil pengukuran diameter zona hambat fraksi etanol, fraksi MeOH-air, fraksi kloroform dan fraksi n-heksan Karang Lunak Sinularia sp. terhadap bakteri Escherichia coli.

\begin{tabular}{lllllll}
\hline Ulangan & $\begin{array}{l}\text { Fraksi } \\
\text { metanol } \\
\text { ekstrak }\end{array}$ & $\begin{array}{l}\text { Fraksi } \\
\text { metanol } \\
\text { air }\end{array}$ & $\begin{array}{l}\text { Fraksi } \\
\text { kloroform }\end{array}$ & $\begin{array}{l}\text { Fraksi } \\
\text { n-heksan }\end{array}$ & $\begin{array}{l}\text { Kontrol } \\
\text { positif } \\
(+)\end{array}$ & $\begin{array}{l}\text { Kontrol } \\
\text { negatif } \\
(-)\end{array}$ \\
\hline 1 & 10 & 8 & 12 & 1 & 26 & 0 \\
2 & 15 & 9 & 9,5 & 0 & 27 & 0 \\
3 & 13 & 7 & 10 & 1,5 & 25 & 0 \\
\hline Rata-rata & 12,67 & 8 & 10,5 & 0,83 & 26 & 0 \\
\hline
\end{tabular}

Gambar1. Diameter zona hambat terhadap E.Coli

Berdasarkan hasil penelitian uji aktivitas antibakteri pada Tabel 3, didapati bahwa ekstrak dan fraksi uji mampu menghambat pertumbuhan bakteri gram negatif yaitu bakteri Escherichia coli. Hal ini ditunjukkan dengan adanya daya hambat (zona bening) yang terbentuk pada fraksi
Gambar 2. Diameter zona hambat terhadap S. aureus

metanol ekstrak 12,67 mm, dan pada fraksi kloroform sebesar 10,5 mm. Hal tersebut menyatakan bahwa fraksi metanol ekstrak dan fraksi kloroform mampu menghambat pertumbuhan bakteri dengan kategori kuat. Pada fraksi metanol-air daya hambat yang terbentuk 
yaitu sebesar $8 \mathrm{~mm}$ dengan kategori sedang, dan yaitu sebesar $0,83 \mathrm{~mm}$. pada fraksi n-heksan dengan kategori lemah

Tabel 4. Hasil pengukuran diameter zona hambat fraksi metanol ekstrak, fraksi $\mathrm{MeOH}$-air, fraksi kloroform dan fraksi n-heksan Karang Lunak Sinularia sp. terhadap bakteri Staphylococcus aureus.

\begin{tabular}{|c|c|c|c|c|c|c|}
\hline Ulangan & $\begin{array}{l}\text { Fraksi } \\
\text { metanol } \\
\text { ekstrak }\end{array}$ & $\begin{array}{l}\text { Fraksi } \\
\text { metanol } \\
\text { air }\end{array}$ & $\begin{array}{l}\text { Fraksi } \\
\text { kloroform }\end{array}$ & $\begin{array}{l}\text { Fraksi } \\
\text { n-heksan }\end{array}$ & $\begin{array}{l}\text { Kontrol } \\
\text { positif } \\
(+)\end{array}$ & $\begin{array}{l}\text { Kontrol } \\
\text { negatif } \\
(-)\end{array}$ \\
\hline 1 & 12 & 10 & 12 & 7,5 & 22 & 0 \\
\hline 2 & 13 & 7 & 9 & 6 & 23 & 0 \\
\hline 3 & 12 & 8 & 10 & 7 & 23 & 0 \\
\hline Rata-rata & 12,33 & 8,33 & 10,33 & 6,83 & 22,67 & 0 \\
\hline \multicolumn{4}{|c|}{$\begin{array}{l}\text { Pada hasil penelitian uji aktivitas } \\
\text { antibakteri pada Tabel } 4 \text { diatas, } \\
\text { menunjukkan bahwa, ekstrak dan fraksi uji } \\
\text { mampu menghambat pertumbuhan bakteri } \\
\text { gram positif yaitu bakteri Staphylococus } \\
\text { aureus. Hal ini ditunjukkan dengan adanya } \\
\text { daya hambat yang terbentuk pada fraksi } \\
\text { Etanol ekstrak sebesar } 12,33 \mathrm{~mm} \text { serta } \\
\text { fraksi kloroform yaitu sebesar } 10,33 \mathrm{~mm}\end{array}$} & \multicolumn{3}{|c|}{$\begin{array}{l}\text { tersebut mungkin terjadi karena pelarut } \\
\text { kloroform mampu menarik senyawa } \\
\text { bioaktif lebih banyak dibandingkan pelarut } \\
\text { yang lain sehingga ekstrak yang dipartisi } \\
\text { oleh pelarut kloroform mengandung } \\
\text { senyawa bioaktif lebih besar, dan oleh } \\
\text { sebab itu bakteri uji lebih peka terhadap } \\
\text { fraksi kloroform dibandingkan dengan } \\
\text { fraksi lainnya. }\end{array}$} \\
\hline
\end{tabular}
dikategorikan kuat, sedangkan untuk fraksi metanol-air menunjukan daya hambat dengan kategori sedang yaitu $8,33 \mathrm{~mm}$ dan pada fraksi n-heksan sebesar $6,83 \mathrm{~mm}$.

Dari hasil pengamatan yang dilakukan didapati bahwa ekstrak etanol mampu menghambat bakteri Gram positif dan bakteri Gram negatif lebih besar dibanding dengan fraksi metanol-air dan fraksi nheksan. Hal ini terjadi oleh karena ekstrak etanol yang diujikan masih berupa ekstrak kasar dan senyawa bioaktif yang bersifat antibakteri sehingga ekstrak tersebut mampu menghambat bakteri lebih baik dari pada fraksi lainnya. Fraksi kloroform juga menunjukkan perbedaan yang sangat nyata yaitu mampu menghambat pertumbuhan bakteri Eschericia coli dan Staphylococcus aureus lebih besar dibandingkan dengan fraksi metanol-air dan fraksi n-heksan. Hal

\section{KESIMPULAN}

Berdasarkan hasil penelitian Aktivitas Antibakteri Ekstrak dan Fraksi Karang Lunak Sinularia sp., maka dapat disimpulkan bahwa ekstrak etanol, fraksi kloroform dan fraksi metanol-air dapat menghambat bakteri Staphylococcus aureus dikategorikan sedang, namun pada fraksi kloroform dan ekstrak kasar dapa menghambat bakteri Escerichia coli dikategorikan kuat. Hasil penelitian ini juga disimpulkan bahwa ekstrak dan fraksi Karang Lunak Sinularia sp. memiliki senyawa bioaktif dengan spektrum yang luas artinya dapat menghambat pertumbuhan bakteri Gram negatif dan Gram positif.

\section{DAFTAR PUSTAKA}


Achmadi, S. 1992. Teknik Kimia Organik. Fakultas Matematika Dan Ilmu Pengetahuan Alam, IPB, Bogor.

Althunibat, O.Y., R. bin Hashim. M. Daud, M. A. Ikeda \& B. I. Zali. 2009 In vitro antioxidant and proliferative activities of three Malaysian sea cucumber species. European Journal of Scientific Research. 37 : 376-387.

Arnold, O. W. \& R.A Birtles. 1989. Soft sediment marine invertebrates of southeast asia and Australia: a guide to identification. Australian Institutes of Marine Science. Australia.

Bonham, K. \& E.E. Held.1963. Ecological observations on the sea cucumber Holothuria atra and Holothuria leucospilota at Rongelap Atoll, Marshall Islands. Pasific Science 17 : 305--314.

Bordbar, S., F. Anwar \& N.Saari. 2011. Highvalue components and bioactives from sea cucumbers for functional foods - a review. Marine drugs 9 : 1761-1805.

Brooks, G. F. J. S. Butel, And L. N. Ornston. 1995. A. Review of Medical Microbiology. Journal of Microbiology. 4 : 197--202.

Buchanan, R. E. And Gibson, E. E. 1974. Bergey's Manual of Determinative of Bacteriology. Baltimore, USA.

Careaga, V. P., C. Bueno, C. Muniain, L. Alche \& M.S. Maier. Antiproliferative, cytotoxic and hemolytic activities of a triterpene glycoside from Psolus patagonicus and its desulfated analog. Chemoterapy. $55: 60-68$.

Christami, G. 2014. Aktivitas Antioksidan \& Tabir Surya Ekstrak Fenolik Dari Cortex Umbi Kayu (Manihot Esculenta) Dari Kota Melonguane. [Skripsi] Program Studi Farmasi Fakultas Matematika Dan Ilmu Pengetahuan Alam, Universitas Sam Ratulangi, Manado.
Cowan, M. 1999. Plant Product as Antimicrobial Agent. Clinical Microbiology Reviews. 12 : 564--582.

Darsono, P. 1998. Pengenalan secara umum tentang teripang (holothurians). Oseana. $23: 1--8$.

Darsono, P., A. Aznam, dan Djamali. 1998. Kepadatan stok teripang pada beberapa lokasi di Indonesia. J. Torani, 14 : 264-272.

Darsono, P. 2003. Sumber daya teripang dan pengelolaannya.Oseana. $28: 1--9$.

Darsono, P. 2007. Teripang (Holothuridae): kekayaan alam dalam keanekaragaman biota laut. J. Oseana, 2 : 1--10.

Davis, W.W. And Stoud, T. R. 1971. Disc Plate Methods Of Microbiological. Antibiotic Assay. Journal Of Microbiology. 22 : 659--665.

Depkes RI, 1986, Sediaan Galenik, 2 \& 10, Departemen Kesehatan RI, Jakarta. 